\title{
A Program Based on the Successful Intelligence Theory for Developing English Creative Writing among Secondary Schoolers Prepared by Marwa Gharib Ebrahim Mohamed*
}

\section{Introduction}

The purpose of the current research was to develop a program based on successful intelligence theory to enhance the English creative writing skills of secondary schoolers. It also aimed at teaching and measuring the effectiveness of the proposed program. Towards this end, this research deals with writing, creative writing, and motivation for language. A pilot study was presented in order to confirm the existence of a problem in writing at the secondary stage and in the students' motivation for writing. The focus of this study was on the macro level of understanding writing and on its creative side.

\subsection{Context of the Problem}

\subsubsection{English Language Teaching (ELT) at the secondary stage}

The main aim of ELT courses at the secondary stage as demonstrated in Hello 6. English for Secondary Schools: Teacher's Guide (2009:1) is providing secondary stage students with the most necessary language, thinking and knowledge acquisition skills for effective communication and understanding competently spoken and written English. English curriculum is designed and taught for developing masterful students who are capable of communicating effectively using the language in real-life contexts and applying it in their daily life communication, listening and reading for comprehension, and using it in spoken and written situations. It also aims at giving students the prerequisite experience and confidence for utilizing these skills in all situations either inside or outside the school in their lives.

According to the same source (Ibid:1), critical and creative thinking skills and awareness of needed strategies for improving language and continuous learning skills assert the need for learning the

\footnotetext{
* Faculty of Education - Suez Canal University
} 
English language and take part in the development of a more aware and dependent learner. ELT courses at the secondary stage aim at assisting students in the process of reaching certain proficiency, behavioral and civic goals, not only in the English language but in the everyday social interactions.(Hello6. English for secondary schools. Teacher's guide: 2009)

As mentioned above there are many goals that the Egyptian Ministry of Education demonstrated for teaching English at the secondary stage. Students are supposed to master dealing with topics in writing in a correct way as well as being able to express their feeling and ideas freely.

ELT courses components of Hello6. English for Secondary Schools are as follows: student's book, workbook, course cassette, a CD-Rom, a website, a course reader and a teacher's guide. The student's book of the Hello. English for Secondary Schools, Year Two course is the lead and basic means of presenting, developing content appropriate for developing the targeted skills. It consists of eighteen main units and six revisions. Writing tasks vary; students are required to write a report, a paragraph about a job, an informal e-mail and a paragraph about helping the environment.

The student's book of the Hello6. English for Secondary Schools, Year One course is the principal means of presenting, contextualizing, practicing and extending the language topics and skills targeted in this stage. Format and content of the student's book consists of eighteen main units based on a structural and communicative syllabus covering a wide range of topics which are intended to motivate and interest students. Those units are entitled: Famous Egyptians, People and their lives, Jules Verne, William Shakespeare, Daniel Defoe, Charles Dickens, Ernest Hemingway, Sherlock Holmes, The power of the mind, Tomorrow's world, Health and safety, It's a small world, Animals in the wild, People at work, Modern wonders, Phobias, The global village, and Holidays with a difference. The previously eighteen units are arranged into groups of three units; at the end of each group of three units, there is a review unit . This makes a total of twenty four units, twelve units of which are to be covered in the first term and twelve in the second term.

The Workbook of the Hello6. English for Secondary Schools, Year One is prepared to accompany the Student's Book, reinforcing the language and the grammatical structures which the students learned in the student's book. The general aims of the workbook are to: 
(1)Practice and consolidate vocabulary, (2)practice and consolidate word derivations and families,(3) practice and consolidate grammatical structures, (4) encourage and facilitate the use of the dictionary, (5)give opportunities to review recent language, (6)consolidate reading and writing skills, (7)encourage and consolidate thinking and discussion skills and finally (8)to develop students' abilities to plan, write and proofread short texts.

The content and format of Workbook of the Hello6 English for Secondary Schools, Year One are designed for the use in class as a follow- up to the Student's book lessons. The core units of the workbook are not intended to test the students, but to give them an opportunity to use and consolidate what is learnt in the Student's Book. Each unit of the Workbook includes tasks and activities which are stimulating and motivating for the students. Those activities include: (1)A variety of grammar practice exercises, (2)a selection of different types of short reading texts,(3) a variety of writing tasks and activities, (4)dictionary exercises, (5)word squares and crossword puzzles, and(6) pictures, photographs and topics to comment on and discuss.

Similarly, The student's book of the Hello7. English for Secondary Schools, Year Two course is the principal means of presenting, contextualizing, practicing and extending the language topics and skills targeted at this stage. The format and content of the student's books are composed of eighteen basic units depending on a structural and communicative syllabus tackling many topics which are motivating and interesting. Those units are entitled: The world of work, Gulliver's Travels, Today's Money, Teamwork, Lord of the Flies, That's amazing, Business around the world, The necklace, The Olympics, Where Today's Food comes from, Moby Dick, A Place to live, Wise Words, King Solomon's Mines, Off the beaten track, Tourism Today, Jurassic Park and Global Issues. The previous eighteen units are arranged into groups of three units; at the end of each group of three units, there is a review unit. This makes a total of twenty four units, twelve units of which are to be covered in the first term and twelve in the second term.

Each main unit contains five pages, each of which fulfills a different function. The first page of each unit sets the scene for the whole unit and presents a listening activity. The second page, concentrates on the language focus and the structural content of the unit containing activities to present and practice the newly presented structure .The third page focuses on reading. It develops both the 
content of the unit and the students' reading skills. The fourth page develops critical thinking skills. The final page concentrates on communication and develops students' skills either in speaking or writing through asking students to write about a topic in English.

Similarly, the content and format of the Workbook of the Hello7, English for Secondary Schools, Year Two are designed for the use in class as a follow- up to the Student's book lessons. The core units of the workbook are not intended to test the students, but to give them an opportunity to use and practice what is learnt in the Student's Book. Each unit of the Workbook includes tasks and activities which are stimulating and motivating for the students. Those activities include: A variety of grammar practice exercises, a selection of different types of short reading texts, a variety of writing tasks and activities such as "rewrite the following sentences using the words in brackets", "write a paragraph of seven sentences on the qualities you admire most in people", "write a reply to a job advertisement", dictionary exercises, word squares and crossword puzzles, and pictures, photographs and topics to comment on and discuss.

The students' book of the Hello. English for Secondary Schools, Year Three course is the principal means of presenting, contextualizing, practicing and extending the language topics and skills targeted in this stage. The format and content of the student's book is composed of eighteen main units based on a structural and communicative syllabus covering a wide range of topics which are intended to motivate and interest students. Those unites are entitled:, Hope: The Prisoner and Stories, Ernest of Zenda, Reach for the Stars, Energy, Christie: N or M, The importance of trees, Building and Engineering, Stevenson: Dr. Jekyll and Mr. Hyde, The power of nature, Science and scientists, Dumas: The Count of Monte Cristo, Festivals and folk music, Women in history, Greene: Travels with my aunt, The future of books, Finding work, Steinbeck: The pearl and lifelong learning. The previously eighteen units are arranged into groups of three units; at the end of each group of three units, there is a review unit. This makes a total of twenty four units, twelve units of which are to be covered in the first term and twelve in the second term.

The Workbook of the Hello. English for Secondary Schools, Year Three is prepared to accompany the Student's Book, reinforcing the language and the grammatical structures which the students learned in the student's book. The general aims of the workbook are: Practicing vocabulary and grammatical structures well, encouraging and 
facilitating the use of the dictionary, giving opportunities to review recent language, enhancing reading and writing skills, developing thinking and discussion skills and finally developing students' abilities to plan, write and proofread short texts. Each unit includes review units, contains four pages aiming to complement lessons one, two, three and five of the Student's book. The review units differ from those in the student's book. Like the practice tests, they are designed to allow students to become more familiar with the testing format of the GSEC Examination before students sit for the exam at the end of the course.

In brief, the contents of both the Students' Book and the Workbooks of the three secondary years including Hello 6, 7, and 8 focus on developing the following basic areas of the English languagereading, speaking, listening, grammar, functions, critical thinking and writing. Creative writing is implicitly included in the units of the curricula.

According to(Hello6. English for secondary schools. Teacher's guide: 2009:2), ELT courses at the secondary stage use standards-based communicative approach for teaching and learning of English. Students are presented with interesting topics and meaningful situations to help them progress in their secondary level language skills. The three ELT courses use and develop the four language skills (listening, speaking, reading and writing) comprehensively in meaningful contexts. The courses are standards based and aim to fulfill the standards set out by the Egyptian Ministry of Education Standards Document. Using and setting specific standards in this context gives no place to rote learning which becomes ineffective because it is insufficient to help students achieve the wider educational goals.

ELT courses at the secondary stage as stated in Hello6. English for secondary schools Teacher's guide (2009), use new materials in which students are helped to make the transition from the previous level by recycling previously studied language and structures in a new context using a more mature content. This approach is intensified and employed throughout the educational units using various tasks and activities in order to deepen the learners' linguistic knowledge and skills. The materials presented in ELT secondary stage courses take in to account learners' development and individual differences.

Teaching English in Egypt, as Abou-Rahma (2015:13) claims, focuses on only two skills which are reading and writing. "Even reading and writing are practiced in an artificial way without any sort of integration to the extent that writing has a separate booklet." He adds 
that there is a deficiency in having authentic writing tasks. This is one of the most outstanding and urgent problems of English language teaching in Egypt. Moreover creative writing teaching, the target of this study needs clear and inspiring writing tasks. By analyzing the contents of the curriculum guidance and teacher's guide of the three years at the secondary stage, it becomes clear that creative writing development in the secondary stage is neglected.

Writing enables students to prob their thoughts, encourag free thinking and learning, motivate written communication and reflection. Once ideas are written, they can be thoroughly examined, and reconsidered, and may be changed. Writing promotes deep thinking and learning enabling individuals to express their own thoughts and beliefs when they view writing as a process.

Writing is a complex concept which is the core of learning in our Egyptian educational system; which requires effective practices and tasks in order to be developed. But how writing is permitted or encouraged or taught varies according to styles or modes of teaching and learning, classroom atmospheres and settings. The teaching of writing in the schools is often restricted by rigid adherence to educational labels and conventions. Many ELT teachers see creative writing as something that must come from a classroom without what is regarded as necessary practices and requirements for developing creative writing.

Identifying precise and specific purposes of writing and for each writing task is necessary for teaching English skills in general and writing creatively in particular. Setting certain purposes enables teachers to control the content and the sequential process of writing and finally to quantify the value of writing with expected grades and standards. To create freely, openly, and imaginatively becomes possible with some sort and degree of regulation of writing.

Despite a large number of stake-holders in education field who acknowledge the importance of developing and encouraging creativity in students, it is still absent in the Egyptian examinations. In spite of the call for 21 st century necessary skills assessment that asserts creativity, the current system of assessment in the Egyptian Ministry of Education focuses on rote learning . As a result teachers are distracted between following the world call for the current century needs or being abided by the traditional teaching and evaluation determined by the Ministry of Education. 
Students develop writing that has little to do with creative emergence, or with an enjoyment of spontaneity, or with the free expression of themselves and their feelings while writing. In Egypt language teaching and assessment do not care enough for creativity in general. As mentioned earlier, developing creative writing, certain instructional procedures in the area of "creative writing skills" should be directly declared and taught in the curriculum. Using valid and reliable assessment methods is necessary. In other words, the actual quality of evaluating students' performance in creative writings should be determined. This should place by well-trained and experienced teachers.

In the current educational system, most English language teachers mainly depend on the traditional exams rather than developing creativity in their students. The teaching and assessment of creativity is undervalued. Task-appropriateness is also required and should be considered in the assessment criteria as the final product should take, for regarding it a creative piece of work.

The most useful and needed idea in assessment of creative writing in Egypt is adopting the authentic assessment integrating all the necessary requirements of authentic assessment. For avoiding subjectivity, there are many alternatives such as using rubric and grading work, self- error analysis, interviews with teachers, and benefitting from portfolios; which provide students with different useful feedbacks, reviewing and revising their products for several times in order to ensure editing a high quality written performance.

In authentic learning programmes, students become more engaged and highly motivated, because it is characterized by presenting interesting and meaningful learning sessions. Furthermore, having similar curriculum and assessment, ensures a positive impact on student learning and therefore a more successful learning process will result. Actually, ELT secondary curriculum specified learning points (in terms of our basic language skills including listening, speaking, reading and writing) are systematically identified and taught. Assessment process and learning is put in place for teachers to control their students' learning progress. Assessment process includes checking for understanding exercises, small quizzes, self-check exercises (selfassessment) and workbook exercises which are corrected by teachers. Concerning writing skills are systematically planned and taught according to various genres such as narrative, descriptive, expository and argumentative essay. The present problem may be identified 
mainly in the first phase of the writing process which is creating and producing creative, new, genuine and authentic ideas for organizing them in a well formed paragraph. Because writing paragraphs is the major characteristic of final exams, nearly all of the students regard this a boring and a hard task to perform for getting success in their final exams. This point negatively affects them causing much stress and anxiety, reducing the students' motivation for learning language in general and writing in particular. A major reason for this problem is that students are unaware of writing stages and suitable needed strategies for writing well (planning, drafting, and reviewing) . Another possible reason is the little time specified for writing inside classrooms. Writing tasks are usually given for homework assignments leaving students helpless to deal with the writing process alone in order to handle the topic for producing a well formed paragraph; this demotivates students and creates negative feelings and attitudes. Creative writing for EFL students is a hard task to do, especially if their English proficiency is not enough. Thus, this research is an attempt to focus on using the successful intelligence theory principles to develop first year secondary stage students' creative writing skills and motivation for language

Regarding the importance of writing in general and the creative writing in particular it became the center of interest of stakeholders in the Egyptian Ministry of Education. It is included in the general objectives of teaching the English language for secondary stage students in order to enable them to express their feelings and opinions freely in English.

Ali (2008) investigated "The effectiveness of creative dramatics strategy in developing EFL primary school pupils' writing skills". The study aimed at investigating the effectiveness of creative dramatics strategy in developing sixth year primary school pupils' EFL writing skills. The creative dramatics included story telling. The participants consisted of eighty students of sixth year primary school. The experimental group students were taught using creative dramatics; on the other hand the control group was taught in the textbook. The results revealed that there were remarkable differences between both the experimental and control groups in the post measurement of the writing test, in favor of the experimental group. Ali concluded that using creative dramatics strategy is highly effective in developing the EFL writing skills of sixth year primary pupils. 
There are, however, many attempts to improve writing at the secondary stage in the Egyptian context. In this respect, El- Geshy (2010), for example, conducted a study aimed at discovering the extent of using the first year secondary stage students the skills of writing processes. El- Geshy concluded that the students were unable to use the writing composition skills. He suggested conducting a study on the extent of having the secondary stage students the skills of writing creatively and stressed the importance of improving these skills in an early age.

In this respect, Mourtaga (2010:12) declared the necessity of exerting many efforts to develop the writing skills of the Arab learners. He claimed "English instructors lack the linguistic competence and practice of writing hypothesizing that they misunderstand the writing process". He also revealed that mastery of English writing requires continuous and serious practice, and exerting much effort from both teachers and learners; recommending conducting more studies in the area of creative writing.

Abd El Halim (2011) investigated "The effectiveness of some active learning strategies in developing the creative writing skills in English and the cooperative attitudes among the preparatory stage students at the experimental language schools". The participants were ninety five students assigned to three randomly selected groups. The first experimental group received training through think- pair share strategy, the second received training through number heads together strategy, whereas the third group received training through round table strategy. Results showed that the experimental groups outperformed in the post administration of the creative writing test, affirming the existence of differences among pre and post measurements of the experimental group in their performances in the post compared to their pre administrations'. Abd El Halim concluded that using some active learning strategies such as cooperative learning strategies were effective in developing the first year preparatory stage student's creative writing skills and cooperative attitudes.

Hafez \& Atiaa (2006) determined the effectiveness of selforganized learning program on developing creative writing skills of secondary stage students. They developed a test measuring the creative writing skills of first year secondary stage students and a self-organized based program in order to develop the identified creative writing skills. They referred to the effectiveness of their program and to the improvement of students' creative writing skills. They ended with 
suggesting conducting more studies to develop the creative writing skills of students in other learning stages.

Almehdar (2013) searched the effect of a suggested electronic blog on developing the creative writing skills of Saudi secondary stage students. The researcher selected a group of first secondary grade students dividing them into two groups, one of them represents the experimental and the other one is the control group. The study results were(1) there is a statistically significant differences between the two measurements of both groups of the study in the post test for creative writing skills as a whole for the benefit of the experimental group.

Adas \& Bakir (2013:23) refer to the existence of writing problems among the Arab learners, mentioning that teaching English writing to Arab learners has many challenges; therefore they are prone to committing errors." If teachers do not highly motivate their students, they will never obtain the desired products as regards the students' ability to write creatively".

Mohammad \& Hussein (2013) explored the effectiveness of using brainstorming, considering it as the first stage of writing process for enhancing and improving students' motivation towards writing paragraphs. They presented many methods to tackle both the writing process and writing product, providing a general introduction about the main types of brainstorming: free and guided stressing the journalistic guided brainstorming. The results revealed that the two applied types of brainstorming are motivating for learners and the most preferred one is the guided brainstorming.

Mohammad \& Hussein (2013:100) also claim that motivation for writing, like motivation for reading, is either intrinsic or extrinsic. The first spout inside the learner when he/she has the desire to practise writing, whereas the second kind happens in order to satisfy the others; to be regarded and recognized by people around him as a clever writer.

In the process approach as Mohammad \& Hussein (2013:105) point out "the emphasis is on the writer's mental and cognitive point of view of writing process its major steps which are brainstorming, planning, revising, editing and rewriting. It is actually thought that this approach tackles skills of writing as creative phases that needs enough time, deep thinking, double sided interaction and providing effective positive feedback." All these steps and procedures will effectively motivate the learners to exert much effort and time in the writing process; making their writings more creative. 
Also Alodwan \& Ibnian (2014) conducted a study exploring the effectiveness of applying the process approach in writing on improving university learners' creative writing skills. They verified that the process approach had a positive effect on the in EFL learners' creative writing skills. According to the results of this study, they suggested paying more attention for creative writing giving more emphasis for the stage of pre writing on account of its basic and important role in the process of writing. They also recommended allowing more opportunities for secondary stage students to express their ideas in order to produce new and genuine ideas and reactions.

\section{Pilot study}

To make sure of the problem of the current study, Ten EFL secondary stage teachers at El-Farouk Omar Secondary School for Boys were asked about their students' creative writing skills and all of them asserted the deep and clear inability of their students to write a composition which requires them to think creatively about the future or to complete a story suggesting an end after giving them two clue sentences. In order to ensure these opinions of secondary stage students inability to write creatively or to express what they feel creatively, the researcher administered a pilot writing test in March 2015 to explore the real situation among a group of first year secondary stage students. The sample of the pilot study consisted of thirty students at El-Farouk Omar secondary school for boys. They were asked to write freely about two topics. The students' paragraphs were corrected in view of ten creative writing skills which are listed as follows:

1. Generation of new ideas,

2. Using of a range of linking devices,

3. Getting ideas together,

4. Making the text coherent to make the reader understand easily,

5. Placing all parts of speech properly,

6. Applying the vocabulary and terminologies appropriately,

7. Using the style of writing suitably to the requirements of the audience,

8. Clarifying the central ideas from the sustaining information,

9. Making use of major components such as subject, verb and object appropriately which can convey the thought of writer clearly to the reader,

10. Applying the accurate words to state the right tense, case and gender. 
The results of the pilot study revealed that the majority of these students were not good and had problems in the previously mentioned creative writing skills. The scores of the pilot study group were very convergent as the highest was twenty-two out of thirty and the lowest score was five out of thirty. This result clarified and confirmed the problem as the students were not able to develop well-organized paragraphs. The percentage of the students' answers to the previously listed and tested sub- skills was less than $50 \%$. The ratios are indicated in the following table:

Table (1) Percentage of students' responses to the sub-skills tested

\begin{tabular}{|c|c|c|}
\hline Creative writing skills & $\begin{array}{l}\text { Correct } \\
\text { responses }\end{array}$ & SD \\
\hline 1. Generation of new ideas, & $30 \%$ & 12 \\
\hline 2. Using of a range of linking devices & $38 \%$ & 10 \\
\hline $\begin{array}{l}\text { 3. Making the text coherent to make the reader understand } \\
\text { it easily }\end{array}$ & $18 \%$ & 12 \\
\hline $\begin{array}{l}\text { 4. Applying the vocabulary and terminologies } \\
\text { appropriately }\end{array}$ & $42 \%$ & 10 \\
\hline $\begin{array}{l}\text { 5. Using the style of writing suitably to the requirements of } \\
\text { the audience }\end{array}$ & $19 \%$ & 10 \\
\hline $\begin{array}{l}\text { 6. Clarifying the central ideas from the sustaining } \\
\text { information }\end{array}$ & $18 \%$ & 12 \\
\hline $\begin{array}{l}\text { 7. Making use of major components such as subject, verb } \\
\text { and object appropriately which can convey the thought } \\
\text { of writer clearly to the reader }\end{array}$ & $31 \%$ & 8 \\
\hline $\begin{array}{l}\text { 8. Applying the accurate words to state the right tense, } \\
\text { case and gender } 30 \%\end{array}$ & $30 \%$ & 12 \\
\hline
\end{tabular}

Analyzing the data given in Table (1-1) above, it became clear that most students failed to detect surface errors in their English written compositions because they only focused on what they wanted to say neglecting what they actually write. The main reason for not discovering mistakes is that they just read and not proofread..Inexperienced writers are almost always inexperienced readers; it is known that producing well-trained English teachers is a dynamic and hard task to perform regarding writing as a process that springs from theory; but emphasizing practice. Beginner writers suffer for holding linguistic rules in mind during writing on account of their unfamiliarity with patterns of sentences to be used in writing on the contrary of speaking. As a consequence, most of the written sentences are featured to be broken into two isolated parts as if two disjointed ideas had been stuck together. 


\section{Statement of the Problem:}

In the light of reviewing the previous studies related to writing, creative writing at the secondary stage and the pilot study and in spite of the importance of the creative writing skill, secondary schoolers' performance in the creative writing skills was not satisfactory. The current study sought to enhance secondary stage students' creative writing skills through developing a successful intelligence- based program and teaching it to secondary stage students.

Therefore, the current research sought to find an answer to the following main questions:

1-What are the required creative writing skills of first year EFL secondary schoolers?

2- What are the features of a successful intelligence theory- based program that may contribute to developing those skills?

3-How far is the program effective in developing creative writing skills among secondary schoolers?

\section{Delimitations}

The research was delimited to:

1. A group of first year secondary stage students in Ismailia.

2. Some creative writing skills needed to be developed for first year secondary stage students.

\section{Method}

Participants \& Research Design:

participants of this research were 62 first year secondary stage students, who were divided into two groups, an experimental group and a control group. The researcher used the quasi experimental design in order to test the effectiveness of the suggested program.

Instruments:

The researcher developed one main instruments in order to fulfill the objectives of the study: a pre-post test of creative writing skills.

The creative writing skills test was designed to measure the following creative writing skills including three main dimensions expressing stages of writing. writing a well organized paragraph about a certain topic, generating ideas or written products that are original and valuable, evaluating ideas and refining them, producing the kind of thinking best suited to the current needs, writing correct, new and logical sentences, using well structural components to make a cohesive meaning, writing a story expressing and eliciting an emotion, developing ideas for stories, organizing a story, eliminating irrelevant 
ideas, reaching conclusions, achieving coherency, developing scenes and chapters within the framework of a larger story, bringing an abstract concept to life, generating fluent, original, elaborated and flexible ideas, writing a story in proper sequence, forming substantial story that includes a beginning, middle and an end, writing original, unusual and unique main idea and content of a story, writing the opening of a story, developing the background, writing an ending, generating descriptions, development of vocabulary, developing characters, improving dialogue and descriptive writing, handling point of view, drafting and redrafting the written work, developing one's own voice more confidently, providing insight into story structure, plot development, producing a broad range of responses or ideas to a given problem or stimulus. Then the creative writing skills checklist has been designed, it consisted of three main dimensions representing stages of writing (pre-writing stage, the while writing stage, and the post writing stage). The first dimension is devoted to pre-writing stage skills. It consisted of one main skill and three sub-skills. The second dimension is concerned with the while writing stage skills. It consisted of one main skill of writing and telling a story and eleven sub-skills derived from it. The third dimension included one main skill, which is consisted of four sub-skills. The whole checklist in its initial form consisted of 18 items.

1. Validity of the checklist.

2. The prepared checklist was submitted to a jury of specialists to validate it and arranging the skills according to their importance. After collecting the copies of the jury members, they were qualitatively analyzed. Recommended modifications and suggestions were done. 
The relative weight of the importance of each creative writing skill

\begin{tabular}{|c|c|c|c|c|c|}
\hline No & $\begin{array}{l}\text { Creative writing } \\
\text { skills }\end{array}$ & $\begin{array}{l}\text { Very } \\
\text { Important } \\
\text { (3) }\end{array}$ & $\begin{array}{l}\text { Important } \\
\text { (2) }\end{array}$ & $\begin{array}{l}\text { Unimportant } \\
\text { (1) }\end{array}$ & $\begin{array}{l}\text { The relative } \\
\text { weight of the } \\
\text { importance }\end{array}$ \\
\hline \multicolumn{6}{|c|}{ Pre-writing stage skills } \\
\hline 1 & $\begin{array}{l}\text { Brainstorming } \\
\text { and generating } \\
\text { of ideas which } \\
\text { are original, } \\
\text { valuable and } \\
\text { useful. }\end{array}$ & 10 & $\mathbf{0}$ & $\mathbf{0}$ & $\begin{array}{l}\text { 3.00 Very } \\
\text { important }\end{array}$ \\
\hline 2 & Evaluating ideas. & $\mathbf{0}$ & 1 & 9 & $\begin{array}{l}1.10 \text { Not } \\
\text { important }\end{array}$ \\
\hline 3 & Testing ideas. & $\mathbf{0}$ & 1 & 9 & $\begin{array}{l}1.10 \quad \text { Not } \\
\text { important }\end{array}$ \\
\hline 4 & $\begin{array}{c}\text { The ability to } \\
\text { write correct, } \\
\text { new and } \\
\text { logical } \\
\text { sentences. } \\
\end{array}$ & 7 & 3 & $\mathbf{0}$ & $\begin{array}{l}2.70 \quad \text { Very } \\
\text { important }\end{array}$ \\
\hline 5 & $\begin{array}{l}\text { Using well } \\
\text { structural } \\
\text { components to } \\
\text { make a cohesive } \\
\text { meaning. }\end{array}$ & 7 & 3 & $\mathbf{0}$ & $\begin{array}{l}2.70 \quad \text { Very } \\
\text { important }\end{array}$ \\
\hline \multicolumn{6}{|c|}{ The while writing stage and narrative framing skills } \\
\hline 6 & $\begin{array}{l}\text { Developing ideas } \\
\text { of the topics of } \\
\text { the stories. }\end{array}$ & 6 & 4 & $\mathbf{0}$ & $\begin{array}{l}\text { 2.60 Very } \\
\text { important }\end{array}$ \\
\hline 7 & $\begin{array}{l}\text { Organizing of } \\
\text { written work. }\end{array}$ & 10 & $\mathbf{0}$ & $\mathbf{0}$ & $\begin{array}{ll}3.00 \quad \text { Very } \\
\text { important }\end{array}$ \\
\hline 8 & $\begin{array}{l}\text { Eliminating } \\
\text { irrelevant } \\
\text { ideas. } \\
\end{array}$ & 5 & 2 & 3 & $\begin{array}{l}2.20 \\
\text { Important }\end{array}$ \\
\hline 9 & Filling in details & $\mathbf{0}$ & 1 & 9 & $\begin{array}{l}1.10 \text { Not } \\
\text { important }\end{array}$ \\
\hline 10 & $\begin{array}{l}\text { Writing a story } \\
\text { in proper } \\
\text { sequence. }\end{array}$ & 10 & $\mathbf{0}$ & $\mathbf{0}$ & $\begin{array}{l}\text { 3.00 Very } \\
\text { important }\end{array}$ \\
\hline 11 & $\begin{array}{l}\text { Writing an } \\
\text { opening for a } \\
\text { story opening. }\end{array}$ & $\mathbf{0}$ & 1 & 9 & $\begin{array}{l}1.10 \quad \text { Not } \\
\text { important }\end{array}$ \\
\hline 12 & $\begin{array}{lr}\text { Living } & \text { the } \\
\text { character } & \text { using } \\
\end{array}$ & $\mathbf{0}$ & 2 & 8 & $\begin{array}{l}1.50 \quad \text { Not } \\
\text { important }\end{array}$ \\
\hline
\end{tabular}




\begin{tabular}{|c|c|c|c|c|c|}
\hline & dialog. & & & & \\
\hline 13 & $\begin{array}{l}\text { Developing the } \\
\text { background }\end{array}$ & $\mathbf{0}$ & 3 & 7 & $\begin{array}{l}1.75 \text { Not } \\
\text { important }\end{array}$ \\
\hline 14 & $\begin{array}{l}\text { Writing an } \\
\text { ending. }\end{array}$ & 10 & $\mathbf{0}$ & $\mathbf{0}$ & $\begin{array}{l}\text { 3.00 Very } \\
\text { important }\end{array}$ \\
\hline 15 & $\begin{array}{l}\text { Developing one's } \\
\text { own voice } \\
\text { more } \\
\text { confidently . } \\
\end{array}$ & 10 & $\mathbf{0}$ & 0 & $\begin{array}{l}\text { 3.00 Very } \\
\text { important }\end{array}$ \\
\hline \multicolumn{6}{|c|}{ Post writing stage skills } \\
\hline 16 & $\begin{array}{c}\text { Reviewing } \\
\text { descriptions. }\end{array}$ & 6 & 4 & $\mathbf{0}$ & $\begin{array}{ll}2.60 \quad \text { Very } \\
\text { important }\end{array}$ \\
\hline 17 & $\begin{array}{l}\text { Reviewing } \\
\text { grammar, } \\
\text { vocabulary of } \\
\text { the whole } \\
\text { written work. }\end{array}$ & 4 & 1 & 5 & $\begin{array}{l}1.50 \quad \text { Not } \\
\text { important }\end{array}$ \\
\hline 18 & $\begin{array}{l}\text { Drafting and re- } \\
\text { drafting the } \\
\text { written work. }\end{array}$ & 10 & $\mathbf{0}$ & $\mathbf{0}$ & $\begin{array}{l}\text { 3.00 Very } \\
\text { important }\end{array}$ \\
\hline
\end{tabular}

*From (1) to less than (1.67) means unimportant.

From (1.67) to less than (2.34) means important

From (2.34) to (3) means very important.

\section{The Creative Writing Skills Test:}

\section{A. Aims of the CWS Test:}

The main purpose of the creative writing test was to measure the first year secondary school students' mastery level in the predetermined creative writing skills.

The creative writing test was designed, It consists of three questions. Question one consists of a group of five topics titles. students were required to read them carefully, then choose the most two preferable two for them and write a paragraph of eight sentences for each. In question two they were asked to write an opening of four sentences for a story entitled " a terrible traffic accident". Question three they were required to write a story of eight sentences about an unforgettable experience they lived. Students were instructed to answer the three questions within one hour. 
B. Establishing the reliability of the test

For identifying the needed time for answering the test, (25) students were chosen randomly from first year secondary schoolers of El-Zohour secondary school in Ismaillia. The test was answered by those students, who were not included either in the experimental group or the control one. The estimated time was two hours for each student to finish the test. The time was determined through calculating the mean time taken by the participants for finishing answering the whole test.

Concerning scoring the creative writing test, it was evaluated as follows: A score ranged from one to three points were set to each response that measure the creative writing skills according to Creative Writing Rubric ( Appendix, 4).Therefore, the total score of the test was 30 points.

C. The CWS Test Validity

The test was submitted to a group of TEFL jury members to validate according to the following terms: (a) the appropriateness of the set questions; (b)the difficulty of the test; (c) the test length; (d) clarity of the given instructions. Considering all the given suggestions of the whole jury members, the test was modified reaching the final form.

D. The CWS Test Reliability

The reliability of the test was calculated by applying the test on (10) secondary schoolers for identifying the CRST reliability. Cronbach's Alpha formula was used; it was found $(0,882)$ which refers that the test is highly reliable. It also indicates a highly internal coherence level of the test.

3. The Suggested Successful Intelligence Theory Based Program:

Description:

1 The program was designed for developing creative writing skills and motivation towards English among first year secondary schoolers.(Appendix, E)

A. Objectives of the SITBP

By the end of the experimentation, secondary schoolers would be able to :

1.Write creatively as a result of developing their creative writing skills.

2.be highly motivated towards English. 
B. The principles of the SITBP

The major principles of successful intelligence theory based program were collected through reviewing the related literature dealt with the successful intelligence theory, activities and its practical applications. Considering all the basics obtained from those sources, the principles can be summarized as follows:

1. Encouraging students to formulate and ask questions, because questioning should be made a part of the daily classroom exchange, not just to answer questions.

2. Providing students with step by step monitoring and feedback.

3. Encouraging students to evaluate through asking them to comment on the strengths and weaknesses of their own work and others'.

4. Asserting the importance of constructive critique.

5. If the students do some creative work teacher should ask them to explain why it is better than the existing ones.

6. Presenting model creativity.

7. Giving students time to think creatively, rewarding creativity and creative efforts.

8. Helping students imagine their viewpoints.

9. Helping students to explore their mistakes in order to correct them.

10. Assigning responsibility in students help them to understand their thinking processes, criticize themselves and take pride in their best work.

11. Encouraging students to analyze the offered information, to evaluate the value of what they learned and compare many situations or problems.

12. Capitalizing the students' strengths and compensating for their weaknesses.

13. Class work and assessments are centered on activities that require analysis, creativity and application.

C. Encouraging creativity is targeted through behaviours such as:

- asking open-ended questions

- tolerating ambiguity

- modeling creative thinking and behaviour

- encouraging experimentation and persistence

- praising students who provide unexpected answers.

D. Teaching the analytical dimension depends on the following tasks:

Analytical based tasks will be used for urging students to think analytically about the given topics in the pre-writing stage. Also in the 
while writing stage they will be asked to critically think about what they write. Finally after finishing writing process they will be asked to evaluate their writings, finding out grammar, spelling and punctuation mistakes. Analytical writing tasks can be listed as follows:

1. Comparing $\&$ contrasting points of view.

2. Criticizing my own \& others work.

3. Thinking clearly \& analytically.

4. Evaluating my \& others points of view.

5. Solving logical problems.

6. Thinking analytically about things.

E. Teaching the Creative dimension includes the following tasks:

The creative writing tasks were essentially depend on encouraging students to creatively think, produce and write more new, varied, flexible and original ideas, solutions descriptions. Creative writing tasks are listed as follows:

1. Using their imagination to come up with ideas,

2. Playing make-believe and pretend games,

3. Thinking of alternative solutions,

4. Thinking in pictures and images,

5. Supposing that things were different,

6. Thinking about what would have happened if certain aspects of the world were different.

7. Acting and role playing.

F. The Practical dimension depends on the following tasks

Practical dimensions based tasks tend to encourage students to integrate what they learned and acquired in the previous two stage for producing new, correct and more flexible writings. Depending on avoiding all the mistakes done in the two previous stages. These tasks can be enumerated and summed up as follows:

1. Putting into practice things they learned,

2. Advising their friends on their problems,

3. Learning by interacting with others,

4. Applying their knowledge,

5. Working and being with others,

6. Adapting to new situations .

G. The Duration of Application of the SITBP 
Experimentation lasted six weeks in the first semester of the academic year 2017-2018 from $9^{\text {th }}$ of November to the $20^{\text {th }}$ of December consisting of seventeen sessions.

H. The teaching Aids

1-Handouts( including titles of paragraphs and pictures for warming up activities)

2-PowerPoint presentations .

I. Materials for the SITBP

The instructional content for the program consisted of titles of paragraphs which were taken from the Student's book (Hello!6). They were used with the experimental group using the SITBP and the control group received instruction through the traditional method.

J. Description of the SITBP

a. The first session was dedicated to orientation, for making the first year secondary scholers aware of the essence and importance of creative writing .Also the successful intelligence theory implications are novel for them; so it was necessary to mentally and emotionally prepare them well for the tasks they are to be involved. For achieving this goal the researcher worked for creating a friendly atmosphere by a simple presentation; illustrating for them that the main aim for this experiment is helping them to write creatively.

b. The second session was dedicated for pre-testing the participants (both the experimental and the control groups) through applying the creative writing test and the motivation scale.

Session three includes applying the prepared activities and tasks for developing the first creative writing skill. Firstly, the intended learning outcome was demonstrated; it was developing their abilities for generating as much flexible, original and valuable ideas as possible.

\section{Data Analysis and Discussion}

After collecting the data, they were analyzed using the t-test and the results were discussed as shown below.

The following statistical methods were used to confirm the hypotheses.

1-t-Test Paired to verify the study hypotheses, i.e. to test the significance of the differences between the pre-and the postapplications. 
2-Effect Size was used for testing the descriptive hypothesis.

Comparison between the experimental group and the control group prior to starting the experiment.

Before administering the SITBP, it was necessary to make sure that there were no differences between the two groups (the experimental and the control) on the mean scores of the creative writing skills test and the motivation scale.

Table (2) t Value for the differences between the experimental and the control groups mean scores on the creative writing skills test prior to starting the experiment

\begin{tabular}{|l|l|l|l|l|l|l||}
\hline $\begin{array}{l}\text { Creative } \\
\text { Writing } \\
\text { Skills Test }\end{array}$ & Groups & No & Mean & S.D & t & Sig at 0,05 \\
\hline Pre-test & Experimental & 31 & $\mathbf{9 , 6 7}$ & $\mathbf{6 , 4 2}$ & .97 & $\mathbf{0 , 3}$ (Not Sig) \\
\hline & Control & 31 & 11,12 & $\mathbf{5 , 2 6}$ & .97 & $\mathbf{0 , 3}$ (Not Sig) \\
\hline
\end{tabular}

\section{Findings}

Findings are displayed in terms of hypotheses of the study as follows:

Hypothesis (1)

Hypothesis one is "There is a statistically significant difference between the mean scores of the experimental and the control groups in the post administration of the creative writing skills test in the post administration in favor of the experimental group". In this respect, the mean scores of the pre -post measurements were calculated. t-Test Paired was used to determine the statistical significance between the mean scores of the pre and post scores of both the experimental and control groups.

The following table presents the related calculations :

Table (3) t test Value for the differences between the mean scores of the experimental and the control group on pre and post creative writing skills test. 


\begin{tabular}{|c|c|c|c|c|c|c|}
\hline \multirow[b]{2}{*}{$\begin{array}{l}\text { Creative } \\
\text { Writing Skills }\end{array}$} & \multirow[b]{2}{*}{ mean } & \multirow[b]{2}{*}{ S. DV } & \multirow[b]{2}{*}{ DF } & \multirow[b]{2}{*}{$\begin{array}{l}\text { t- } \\
\text { value }\end{array}$} & \multirow[b]{2}{*}{ Sig. } & \multirow{2}{*}{$\begin{array}{l}\text { Effect Size } \\
\text { (Eta- } \\
\text { Squared) } \\
\text { formula }\end{array}$} \\
\hline & & & & & & \\
\hline $\begin{array}{l}\text { Experimental } \\
\text { Group } \\
\end{array}$ & 21.32 & 4.3 & \multirow{2}{*}{60} & 9.65 & 0.05 & 0.6 \\
\hline $\begin{array}{ll}\text { The } & \text { Control } \\
\text { Group } & \end{array}$ & 9.48 & 5.2 & & 9.65 & 0.05 & \\
\hline
\end{tabular}

Table (4-2) above indicates that there are statistically significant and clear differences between the mean scores of the experimental and the control groups at the level of $(0.05)$, in favor of the experimental group. T-Value between the two groups is 9.65 at $(0.05)$ level. Effect Size was also calculated using Eta-Squared formula as( 0.6$)$. Therefore, this finding refers to the positivity and success of the used program on developing creative writing skills.

Fig (1). The differences between the two groups (the experimental and the control) in the post application of the creative writing skills test

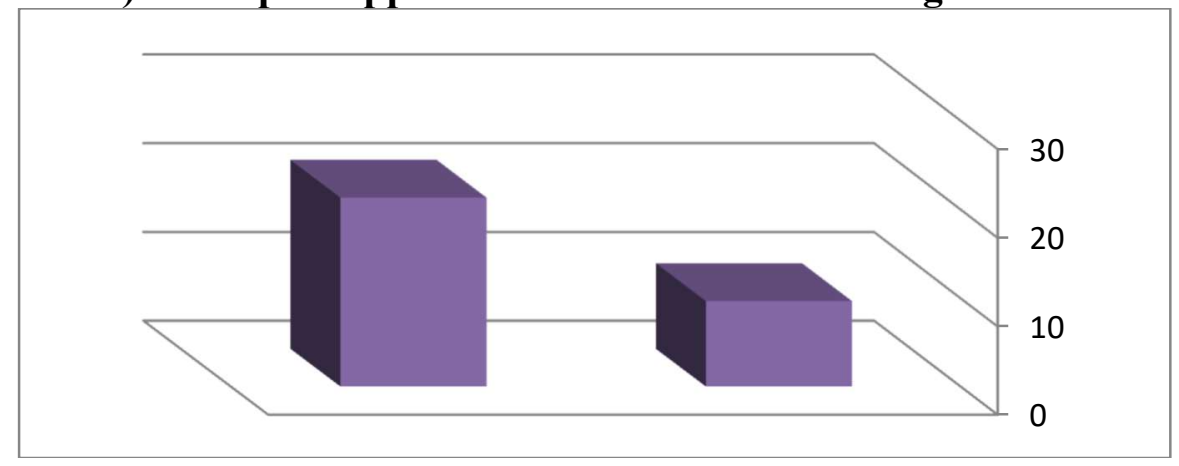

Hypothesis(2) Experiment Control

The second hypothesis stated that "There is a statistically significant difference at $(0.05)$ level between the mean scores of the experimental group in the pre administration of the creative writing skills test and those of the post administration of the same test in favor of the post administration" is tested using the t-test. Mean scores, Standard deviations and t-test for paired samples were calculated for verifying the statistical significance.

Table(4) $T$ test Value for the differences between the total mean scores on the pre and post application of the creative writing skills test of the experimental group 


\begin{tabular}{|c|c|c|c|c|c|c|c|c|}
\hline Skills & $\begin{array}{l}\text { The group } \\
\text { The } \\
\text { Experimenta } \\
\text { I Group }\end{array}$ & $\mathbf{N}$ & $\begin{array}{l}\text { Mean } \\
\text { Score } \\
\text { s }\end{array}$ & $\begin{array}{l}\text { Standar } \\
\text { d } \\
\text { Deviatio } \\
\text { n }\end{array}$ & $\begin{array}{l}\mathbf{D} \\
\mathbf{F}\end{array}$ & $\begin{array}{l}\text { t- } \\
\text { Valu } \\
\text { e }\end{array}$ & $\begin{array}{l}\text { Significan } \\
\text { ce Value } \\
\alpha\end{array}$ & $\begin{array}{l}\text { Significan } \\
\text { ce at level } \\
0.05\end{array}$ \\
\hline \multirow{2}{*}{$\begin{array}{l}\text { Creativ } \\
\text { e } \\
\text { Writin } \\
\text { g Skills } \\
\text { test }\end{array}$} & $\begin{array}{l}\text { The pre } \\
\text { administrati } \\
\text { on }\end{array}$ & $\begin{array}{l}\mathbf{3} \\
\mathbf{1}\end{array}$ & 9.67 & 6.42 & $\begin{array}{l}3 \\
0\end{array}$ & \multirow{2}{*}{9.36} & \multirow{2}{*}{0.00} & \multirow{2}{*}{ Sig } \\
\hline & $\begin{array}{l}\text { The post } \\
\text { administrati } \\
\text { on }\end{array}$ & $\begin{array}{l}3 \\
1\end{array}$ & 21.32 & 4.34 & $\begin{array}{l}3 \\
0\end{array}$ & & & \\
\hline
\end{tabular}

Table (4) shows that there is a statistically significant difference at $(0.05)$ level between the mean scores of the pre-post application of the creative writing skills test of the experimental group in favor of the post measurement. This result proves that the creative writing skills of participants improved. This asserts the positive effect of the (SITBP) on developing their creative writing. Therefore, the third hypothesis of the study is verified.

These positive results may be retrieved to the major principle of the successful intelligence theory that asserts the necessity of discovering errors that students done during writing and gaining insights of their own strengths and weaknesses. Moreover, allowing them to avoid these errors next times and reinforcing their selfconfidence .In addition, this improvement may be due to the instructor's continous comments and feedback.

It is worth mentioining that, the previously reported result largely agrees with those of Sternberg (2005); Temizkan (2011); Ryan(2014); and Asri(2015) which confirmed the effectiveness of applying the successful intelligence theory principles and teaching teqniques in developing creatitity and creative writing skills among learners.

Fig. (2) The differences between the pre and post applications of the creative writing skills test 


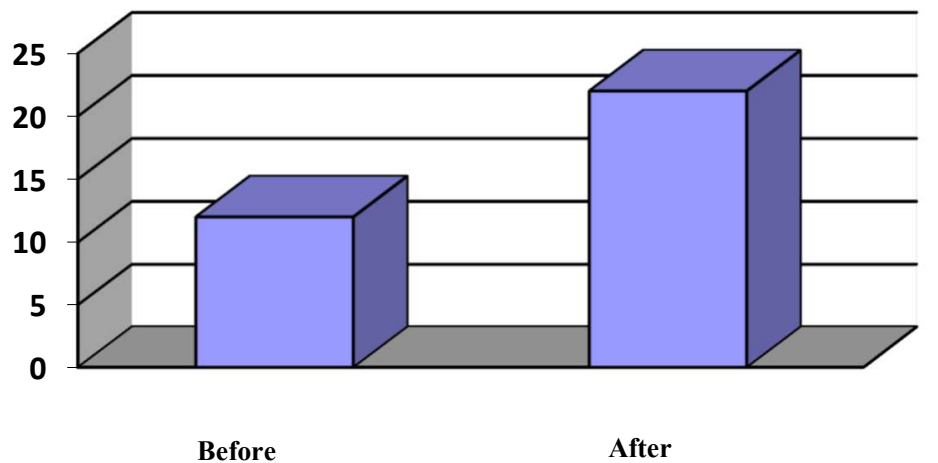

These results revealed that using and applying successful intelligence theory principles and related activities contributed to achieving an improvement in raising motivation level among the participants. This change can be attributed to using different writing activities; encouraging group working and requiring expressing themselves freely. Knowing that the purpose of the program and feedback was not for just evaluation and that the main aim was benefitting from those mistakes in order to avoid them afterwards. All these reasons helped in motivating the participants and reduced their fear and made them more enthusiastic to take part in writing activities.

\section{Recommendations}

In the light of the results of the study, the following may be recommended:

1-EFL writing skill courses should include successful intelligence theory triarich dimensions(creative-analytical-practical) for developing critical reading skills among secondary stage students.

2-EFL teachers should be trained to utilize successful intelligence theory in classes.

3-EFL student teachers courses should adopt implications derived from successful intelligence theory in developing their creative writing skills.

4-Considering the main aim and principle of successful intelligence theory which is stressing students' strengths and helping them to overcome their weaknesses and drawbacks in all instructional stages.

5- Successful intelligence theory with its three dimensional steps should be used in teaching critical reflection thinking among EFL prospective teachers.

Suggestions for Further Research 
In the light of the results and recommendations set before the present research, the following are some suggestions for further research:

1-Further studies can be conducted to investigate the effect of successful intelligence theory on preparatory stage students' creative writing skills .

2- Further studies can be conducted to investigate the effect of successful intelligence theory on reading, speaking, and listening skills.

3- Further studies can be conducted to investigate the effect of successful intelligence theory on EFL prospective teachers' critical reading skills.

4- Further studies can be conducted to investigate the effect of successful intelligence theory on developing primary stage students' writing skills.

5-Further studies can be done to examine the effect of successful intelligence theory on EFL student teachers' creative writing skills.

\section{References}

Adas,D.\&Bakir,A.(2013).Writing difficulties and new solutions: Blended learning as an approach to improve writing abilities. International journal of humanities and social science.Vol.3.

Ahmed, A.(2010).Students' problems with cohesion and coherence in EFL essay writing in Egypt: Different perspectives. Literacy information and computer education journal.V.1.issue 4.

Al-Khudair, A.(2010). Effectiveness of program based on mind habits in developing creative writing skills in poetry field for high school female students in Saudi Arabia. Proceedings of the Saudi Association for Research in Education.

Alodwan, T.\&Ibnian,S. (2014). The effect of using the process approach to writing on developing university students' essay writing skills in EFL. Review of arts and humities, vol.3.

Caramazza, A. (2012). Issues in reading, writing, and speaking: A neuropsychological perspective. Dordrecht: Kluwer Academic.

Charalambous, A.(2011).Learner training: Towards improving secondary students' writing skills. London: Longman.

Chenoweth, $\mathrm{N}$., \& Hayes, J. (2003). The inner voice in writing. Written Communication, Journal of Memory and Language, 27. Kluwer Academic. 
El-Geshy, S. (2010). Using first year secondary stage students' the writing processes in English. Journal of Damascus.Vol.26.

Farouk, A.(2011). A program for developing creative writing skills of French student teachers in view of the communicative approach. Unpublished Master Thesis.

Hafez, W\&Atti,G.(2006). Effectiveness of a self regulated learning program on developing creative. writing skills of secondary stage students.Vol.16 .

Ibrahim,W. (2011). The effect of computer enhanced learning through the use of Asynchronous discussion on improving writing and student perception of technology mediated environment .Research journal specific education. Issue No.21.

Kaufman, S.(2004). Applying the theory of successful intelligence to psychotherapy training and practice. Imagination, cognition and personality.

, Vol. 23(4).

Kellogg,R. (2008). Literacy and Language Teaching. Cambridge: Cambridge University Press.

LO, C. (2009) An application of the Triarchic Theory of Intelligence to students of English in a Taiwanese university: Reflections of an action researcher. Doctoral thesis, Durham University. Available at Durham E-Theses Online: http://etheses.dur.ac.uk/61/.

Mourtaga, K.(2010). Poor writing in English: A case of the Palestinian EFL learners in Gaza strip.

Oxford, R .(1993): Research on second language learning strategies issues in second language teaching and learning.Annual review of Applied Linguistics.Vol.13.

Palos, R.\&, Maricutoiu, L.(2013). Teaching for Successful Intelligence Questionnaire (TSI-Q) - a new instrument developed for assessing teaching style. Journal of educational science and psychology, Vol. LXV No. 1

Saricaoglu, A \&Arikan,A.(2009).A study of successful intelligence and foreign language success and some variables. Journal of theory and practice in education.Ed.506218.

Sternberg, R. (2002). Successful intelligence. New York: Plume.

Sternberg,R\&Grigorenko,E. (2002)The Theory of Successful Intelligence as a Basis for Gifted Education. http://gcq.sagepub.com/content/46/4/265. 
A Program Based on the Successful Intelligence --------- Marwa Gharib

Sternberg, R. (2004). Successful intelligence as a basis for entrepreneurship. Journal of Business Venturing, 19,

Sternberg, R. \& Grigorenko, E. (2004). Successful intelligence in the classroom. Theory into practice, 4

Sternberg,R.(2005)The theory of successful intelligence.Revista Interamericana de Psicología/Interamerican Journal of Psychology - 2005, Vol. 39, Num. 2 .

Sternberg,R.\& Grigorenko, E .(2010). Teaching for Successful Intelligence:

Principles, Procedures, and Practices .Journal for the Education of the Gifted.

Tigner, S. (2000). Triarchic theories of intelligence: Aristotle and Sternberg. History of Psychology, 3(2).

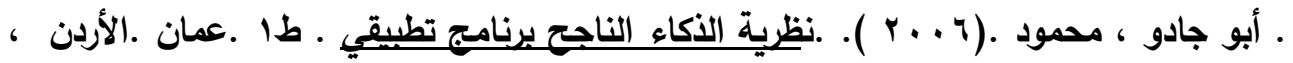

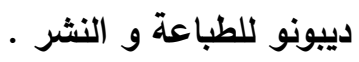

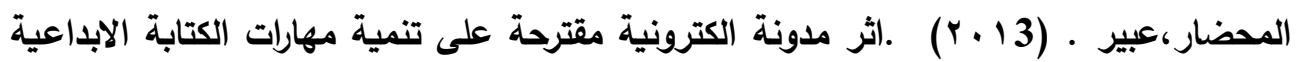

لاى طالبات المرحلة الثانوية.رسالة ماجستير غير منشورة. كلية التربية.جامعة الرياض.

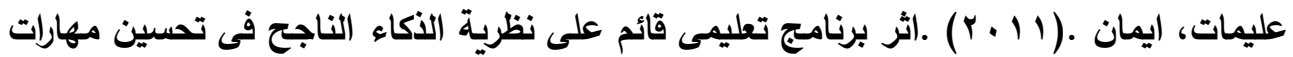

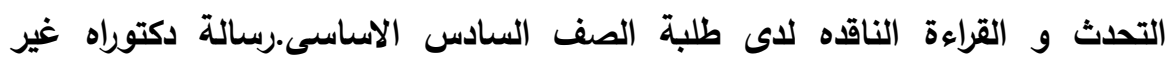

$$
\text { منشوره .كلية التربية. جامعة اليرموك. }
$$

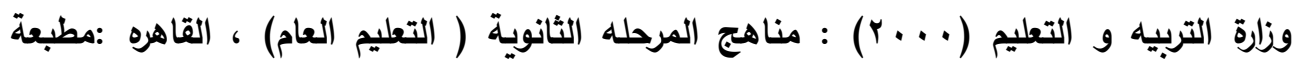




\begin{abstract}
The aim of the current research was to develop the first year secondary schoolers' creative writing skills. A creative writing skills checklist, and a creative writing skills test were developed and validated. The experimental intervention was a successful intelligence theory based program. The participants of the current study were (62) female students who were purposefully chosen from El-Zohour secondary school in Ismailia. They were equally divided into two groups ( Control and Experimental). A creative writing skills test was pre administered. The prepared program based on the successful intelligence theory was taught. The test was post administered. The data were collected and statistically analyzed. The results revealed that there were statistically significant differences between the mean scores of the control and experimental groups on the test in favor of the experimental group students. Results also showed that there were statistically significant differences between the mean scores of the pre and post measurements of the experimental group in their performances in both the creative writing test in favor of the post measurement. Accordingly it was concluded that clarified that the successful intelligence theory based program had a positive effect on developing creative writing skills among secondary schoolers.
\end{abstract}

